\title{
KONTRIBUSI PAYMENT FOR ENVIRONMENT SERVICES (PES) TERHADAP KEBERLANJUTAN WISATA SELAM DI KAWASAN KONSERVASI LAUT GILI MATRA
}

\section{PES (Payment For Environment Services) Contribution for Sustainability of Scuba Diving Tourism in Gili Matra Conservation Area}

\author{
*Lalu Solihin"1, Tridoyo Kusumastanto', Akhmad Fauzi' dan Fredinan Yulianda ${ }^{2}$ \\ ${ }^{1}$ Fakultas Ekonomi dan Manajemen, Institut Pertanian Bogor. \\ Jl. Agatis Kampus IPB Darmaga, Dramaga, Bogor, Jawa Barat 16680, Indonesia \\ ${ }^{2}$ Fakultas Perikanan dan IImu Kelautan, Institut Pertanian Bogor. \\ Jl. Agatis Kampus IPB Darmaga, Dramaga, Bogor, Jawa Barat 16680, Indonesia \\ Diterima tanggal: 5 Maret 2019 Diterima setelah perbaikan: 21 Agustus 2019 \\ Disetujui terbit: 9 Desember 2019
}

\begin{abstract}
ABSTRAK
Kawasan konservasi yang digunakan sebagai lokasi wisata selam, berpotensi menimbulkan kerusakan ekosistem sumberdaya terumbu karang yang ada disekitarnya. Wisatawan yang memperoleh kepuasan ketika menikmati keindahan alam laut, maka mereka harus memberikan kontribusi balik terhadap lingkungan. Dana kontribusi tersebut akan dipergunakan untuk biaya perbaikan kualitas lingkungan yang rusak akibat aktivitas wisatawan. Oleh karena itu, tujuan penelitian ini adalah untuk menganalisis seberapa besar kontribusi PES terhadap keberlanjutan ekosistem terumbu karang sebagai penunjang kegiatan wisata selam, dan bagaimana mekanisme pungutan PES yang efisien dan optimal. Hasil penelitian menunjukkan bahwa, iuran PES dari pengguna jasa wisata selam berpengaruh signifikan terhadap pertumbuhan ekosistem terumbu karang apabila iuran tersebut dikelola secara baik dan benar. Dalam skema pungutan PES yang diusulkan pada artikel ini adalah dengan melibatkan seluruh stakeholder yang berkepentingan terhadap kawasan konservasi ke dalam lembaga pengelola dana PES.
\end{abstract}

Kata Kunci: payment for environment services (PES); ekosistem terumbu karang; wisata selam; kawasan konservasi; Gili Matra

\section{ABSTRACT}

Conservation areas which are utilized as diving tourism location, have potencials to cause damages of the surrounding thicks of coral reef ecosystem resources. Tourists who have gained satisfaction when enjoying the beauty of the nature "under the sea", hence they must provide reciprocal contributions for the environment. The contribution funds will be used for costs of damaged environmental quality restoration due to tourist activities. Therefore, the purpose of this research is to analyze the magnitude of PES' contribution to the sustainability of coral reef ecosystems as a mean to support diving tourism activities, and how the collection mechanism of PES is being efficient and optimal. Research results indicated that, $P E S$ fees from users of diving tourism services have significant effects on growth of coral reef ecosystem if the fees are managed properly and correctly. In the collection scheme of PES which is proposed in this article is by involving the entire stakeholders who have importance to the conservation areas into funding management institution for PES.

Keywords: payment for environment services (PES), coral reef ecosystem, scuba dive, conservation area, Gili Matra

\section{PENDAHULUAN}

Hingga Desember 2013, Kementerian Kelautan dan Perikanan telah mencadangkan Taman Nasional Perairan seluas 3.521.130,01 Hektare (Ha) dan memfasilitasi pencadangan Kawasan Konservasi Perairan Daerah (KKPD) seluas 5.561.463,09 Ha. Selain itu, Kementerian Kelautan dan Perikanan juga telah menetapkan 8 (delapan) kawasan konservasi yang diserahterimakan dari Kementerian Kehutanan dengan luas keseluruhan $723.984,00 \mathrm{Ha}$. Hingga saat ini kawasan konservasi laut yang diinisiasi dan pengelolaannya berada di bawah wewenang Kementerian Kehutanan mencapai luas keseluruhan 4.694.947,55 $\mathrm{Ha}$. Sampai akhir 2013, luas keseluruhan kawasan konservasi perairan di Indonesia telah mencapai 15.764.210,85 Ha (KKP, 2013). 
Taman Wisata Perairan Gili Matra (TWP Gili Matra) merupakan salah satu kawasan konservasi perairan yang ada di Kabupaten Lombok Utara Provinsi Nusa Tenggara Barat. Kawasan ini merupakan salah satu kawasan yang dimanfaatkan sebagai kawasan wisata bahari, khususnya wisata selam. Kawasan ini tidak hanya memberikan kontribusi ekonomi yang cukup signifikan terhadap perekonomian daerah, tetapi juga menimbulkan biaya konservasi yang cukup besar untuk perbaikan kualitas lingkungan yang rusak akibat aktivitas wisata selam maupun yang rusak secara alami. Pada tahun 2015 kontribusi sektor pariwisata bahari terhadap PAD sebesar $44 \%$ atau atau 40,4 milyar rupiah per tahun (Dispenda, 2015).

Para wisatawan memiliki peran yang cukup signifikan terhadap kerusakan terumbu karang. Setiap wisatawan yang menyelam memiliki peluang untuk melakukan pangambilan karang, menginjak karang, maupun menendang karang. Dampak negatif inilah yang kemudian menjadi biaya dalam setiap aktivitas ekonomi. Menurut European Commission, (2005) dalam (Bachmann \& Kamp, 2017) menyebut bahwa dampak negatif ini seringkali ini diekspresikan dalam bentuk uang yang kemudian dijadikan sebagai biaya eksternal.

Padahal yang menjadi daya tarik bagi wisatawan di TWP Gili Matra adalah keindahan ekosistem terumbu karang dengan segala biota yang ada disekitarnya. Selain berfungsi sebagai penyedia tempat tinggal, penyedia makan, dan tempat berkembang biak bagi berbagai biota laut, terumbu karang juga memberikan nilai ekonomi yang cukup tinggi bagi masyarakat disekitarnya melalui produk jasa lingkungan. Jumlah pengunjung yang datang terus menerus meningkat (lihat Tabel 1), disatu sisi memberikan manfaat ekonomi yang tinggi bagi masyarakat dan perekonomian daerah. Tetapi disisi lain akan berdampak negatif terhadap lingkungan ekologi disekitarnya. Namun karena rendahnya apresiasi masyarakat terhadap nilai dari jasa lingkungan dan kurangnya mekanisme kompensasi menyebabkan sumber daya alam terus mengalami degradasi (Danida, 2011).

Hasil penelitian (Zhu \& Zhao, 2015), menjelaskan bahwa yang dipahami masyarakat tentang Polluters Pays Principle (PPP) antara lain: 1) sebuah prinsip ekonomi yang berupaya untuk menginternalisasi biaya atas polusi yang disebabkan oleh pencemar, 2) PPP mengharuskan pencemar membayar keadaan darurat yang muncul sebagai pengganti biaya, 3) PPP mengharuskan pencemar untuk membayar kompensasi kepada masyarakat yang terkena polusi. Agar kegiatan ekonomi dalam pemanfaatan sumber daya perairan dapat optimal, maka segala bentuk biaya yang muncul akibat dari aktivitas wisata, harus diinternalisasi sebagai biaya eksternal yang harus dibebankan kepada wisatawan langsung maupun tidak langsung melalui penyedia jasa wisata.

Oleh karena itu, perlu disusun skema pembayaran untuk jasa lingkungan yang dinikmati wisatawan kepada pengelola kawasan sehingga pengelola kawasan memiliki anggaran yang cukup untuk menjaga kawasan TWP Gili Matra yang digunakan untuk kawasan wisata. Penelitian dilaksanakan di kawasan konservasi Taman Wisata Perairan Gili Matra Kabupaten Lombok Utara Provinsi Nusa Tenggara Barat. Kawasan ini termasuk kawasan konservasi yang dimanfaatkan sebagai kawasan wisata perairan. Kawasan ini dikelola oleh Kementerian Perikanan dan Kelautan Republik Indonesia dengan total luasan kawasan seluas $2.954 \mathrm{Ha}$ yang terdiri dari tiga pulau kecil yaitu Gili Ayer, Gili Meno, dan Gili Trawangan, dimana luas daratan seluas 665 $\mathrm{Ha}$ dan selebihnya perairan laut (Kementerian Kelautan dan Perikanan, 2013). Meskipun secara yuridis, kawasan ini menjadi kewenangan Kementerian Kelautan dan Perikanan, namun secara administratif, kawasan ini masuk kedalam wilayah Kabupaten Lombok Utara, dan penerima manfaat ekonomi dari kegiatan wisata di kawasan ini adalah pemerintah daerah melalui pungutan pajak daerah dan retribusi.

Secara aspek yurudis formal, kawasan konservasi TWP Gili Matra merupakan kawasan milik negara (state property right), sehingga segala sesuatu yang terkait dengan kawasan konservasi ini menjadi tanggungjawab negara. Berdasarkan wewenang pengelolaannya, kawasan TWP Gili Matra sejak tanggal 15 Maret 2001 sampai dengan 4 Maret 2009 berada di bawah pengelolaan BKSDA NTB Departemen Kehutanan, sesuai dengan Surat Keputusan Menteri Kehutanan Nomor: 99/Kpts-II/2001. Selanjutnya sejak tanggal 4 Maret 2009 wewenang pengelolaannya berada di bawah Departemen Kelautan dan Perikanan sesuai dengan berita acara serah terima kawasan suaka alam dan kawasan pelestarian alam dari Departemen Kehutanan kepada Departemen Kelautan dan Perikanan Nomor: BA.01/MenhutIV/2009 dan Nomor BA.108/MEN.KP/III/2009. Selanjutnya berdasarkan Keputusan Menteri 
Nomor 67/MEN/2009 tentang Penetapan Kawasan Konservasi Perairan Nasional Pulau Gili Ayer, Gili Meno, dan Gili Trawangan di Provinsi Nusa Tenggara Barat, pada tanggal 3 September 2009 wewenang pengelolaannya berada pada BKKPN Kupang sebagai Unit Pelaksana Teknis yang bertanggung jawab di lapangan.

Dengan demikian, Balai Kawasan Konservasi Perairan Nasional (BKKPN) memiliki kewenangan penuh atas pengelolaan kawasan konservasi TWP Gili Matra. Siapapun yang menerima manfaat secara langsung dari keberadaan sumber daya yang ada disekitar kawasan konservasi, harus memberikan kontribusi atau imbalan finansial terhadap BKKPN. Lembaga ini juga berhak melarang siapa saja yang akan melakukan kegiatan apapun di sekitar kawasan konservasi, kecuali atas ijin dari BKKPN selaku pengelola.

BKKPN merupakan lembaga negara yang berada di bawah Kementerian Kelautan dan Perikanan Republik Indonesia yang berkantor di seluruh kawasan konservasi di Indonesia, salah satunya adalah di Kawasan Konservasi TWP Gili Matra Kabupaten Lombok Utara Provinsi Nusa Tenggara Barat. Lembaga diberikan kewenangan atas nama negara untuk mengelola seluruh kawasan konservasi di Desa Gili Indah, mulai dari daratan hingga perairan, termasuk biota yang ada didalam perairan. Tak terkecuali ekosistem terumbu karang dan seluruh biota yang terkait didalamnya, merupakan hak milik dari Negara yang dikelola BKKPN. Keberadaan ekosisterm terumbu karang ini dapat memberikan kepuasan bagi setiap wisatawan yang datang berwisata kekawasan ini.

Hasil penelitian (Zhu \& Zhao, 2015), menjelaskan bahwa yang dipahami masyarakat tentang Polluters Pays Principle (PPP) antara lain: 1) sebuah prinsip ekonomi yang berupaya untuk menginternalisasi biaya atas polusi yang disebabkan oleh pencemar, 2) PPP mengharuskan pencemar membayar keadaan darurat yang muncul sebagai pengganti biaya, 3) PPP mengharuskan pencemar untuk membayar kompensasi kepada masyarakat yang terkena polusi. Oleh karena itu, dalam Pasal 3 Peraturan Pemerintah Republik Indonesia Nomor 46 Tahun 2017 Tentang Instrumen Ekonomi Lingkungan Hidup menyebutkan Instrumen Ekonomi untuk melindungi keberadaan sumberdaya alam, termasuk ekosistem terumbu karang tersebut meliputi: a) perencanaan pembangunan dan kegiatan ekonomi; b) Pendanaan Lingkungan
Hidup; dan c) Insentif dan/atau Disinsentif. Sehingga bagi wisatawan yang memperoleh kepuasan ketika menikmati ekosistem terumbu karang tersebut, diperbolehkan dipungut sejumlah uang berupa insentif yang akan dimanfaatkan untuk menjaga kelestarian ekosistem terumbu karang. Sebaliknya, wisatawan dapat diberikan insentif jika mereka mampu membuat ekosistem terumbu karang menjadi lebih baik. sehingga keberadaan BKKPN berperan sangat signifikan terhadap keberlanjutan ekosistem terumbu karang. Keterbatasan kemampuan secara finansial sangat menentukan keberhasilan lembaga ini untuk tetap menjaga terumbu karang tetat lestari.

Jenis data yang digunakan dalam penelitian ini adalah data sekunder dan primer. Data sekunder yang dikumpulkan meliputi statistik jumlah pengunjung dan data-data yang terkait dengan WTP, biaya dan manfaat program konservasi di TWP Gili Matra, data beberapa hasil penelitian terdahulu yang relevan dengan tujuan penelitian. Data primer yang dikumpulkan meliputi kebutuhan biaya konservasi, iuran wisatawan, kelembagaan pengelolaan, stakeholder yang terlibat dalam pemanfaatan sumberdaya di TWP Gili Matra.

Metode pengumpulan data dilakukan dengan menggunakan teknik observasi dan survei. Teknik survei ini dilakukan dengan cara melakukan wawancara dengan secara langsung kepada penyedia jasa wisata selam yang melakukan pemungutan iuran PES kepada wisatawan, yayasan Eco Trust selaku pengelola dana iuran wisatawan, tokoh masyarakat. Teknik pemilihan sampel yang digunakan yaitu secara sengaja (Purposive Sampling). Sampel ditentukan secara sengaja untuk mendapatkan data yang akurat dan komprehensip. Sampel terlebih dahulu diidentifikasi berdasarkan kapasitas dan kewenangan responden untuk mendapatkan informasi yang dirancang menggunakan metoda analisis yang diuraikan dibawah ini.

\section{KARAKTERISTIK WISATA SELAM GILI MATRA}

Wisata perairan di Gili Matra merupakan salah satu tujuan destinasi wisata perairan nasional yang berada di kawasan konservasi Taman Wisata Perairan (TWP) di Desa Gili Indah Kabupaen Lombok Utara Provinsi Nusa Tenggara Barat. Obyek wisata yang ditawarkan tidak hanya wisata pantai dengan panorama alam yang indah, tetapi wisata alam bawah laut dengan keindahan terumbu karang serta keanekaragaman hayati yang 
ada disekitarnya. Permintaan wisata yang terus meningkat akan berdampak pada peningkatan kebutuhan para wisatawan. Jumlah penyedia jasa juga mengalami peningkatan, tentu saja akan berdampak pada kesempatan kerja baru bagi masyarakat disekitarnya.

Kawasan ini mulai jadikan kawasan wisata sejak tahun 1990-an, dimana sebelumnya kawasan ini merupakan pulau tak berpenghuni yang dijadikan kawasan perkebunan kelapa dan tempat singgah sementara oleh nelayan yang melaut. Belakangan setelah kawasan ini mulai ramai dikunjungi wisatawan, masyarakat setempat mulai mendirikan bangunan sederhana hingga lama kelamaan menjadi rumah tinggal di lahan dengan status hak guna usaha. Hingga saat ini, status lahan di kawasan TWP ini adalah lahan milik negara setelah HGU yang diberikan kepada pihak swasta telah berakhir masa kontraknya.

Meskipun sudah ada aturan mengenai pembatasan jumlah bangunan di kawasan TWP Gili Matra, namun masih saja ada bangunan yang dibangun secara liar, khususnya bangunan yang berada di sepadan pantai. Tren kunjungan yang terus meningkat menyebabkan permintaan terhadap sarana penunjang wisata juga terus meningkat. Begitu juga dengan permintaan wisata selam, maka jumlah penyedia jasa wisata selam juga terus meningkat. Namun yang menjadi masalah adalah luasan kawasan wisata yang tidak meningkat. Sehingga kepadatan dalam titik lokasi selam akan semakin tinggi. Dampaknya adalah tingkat kenyamanan yang tidak optimal dan peluang kerusakan ekosistem terumbu karang juga semakin besar.

Pasar wisata selam di TWP Gili Matra lebih didominasi oleh wisatawan asing dibanding dengan wisatawan lokal. Begitu juga dengan penyedia jasa wisata selam, pemilik maupun operator wisata sebagian besar dimiliki oleh pengusaha asing. Khusus untuk penyedia jasa selam di Gili Matra, tercatat hanya satu unit penyedia jasa selam yang dimiliki oleh pengusaha lokal, selebihnya pengusaha asing dari berbagai negara. Hal ini menunjukkan bahwa jasa wisata ini sangat tergantung pada pihak asing, dimana yang menerima manfaat adalah orang asing dan yang memberi manfaat juga pihak asing. Sedangkan yang menerima dampak negatifnya adalah masyarakat sekitarnya, kalaupun ada manfaat ekonomi yang diterima jumlahnya tidak sebanding dengan nilai kerusakan akibat aktivitas wisatawan.

Dalam pemanfaatan sumber daya wisata perairan terdapat 28 unit penyedia jasa wisata perairan dan jumlah pengguna jasa yang heterogen, baik dari asal wisatawan maupun dari usia serta tingkat pendidikan pengguna jasa. Dalam analisa ekonomi dikenal dengan istilah Pasar Persaingan Sempurna. Persaingan sempurna merupakan struktur pasar yang paling ideal karena dianggap sistem pasar ini adalah struktur pasar yang akan

Tabel 1. Distribusi Wisatawan yang Berkunjung ke TWP Gili Matra Tahun 2014.

Table 1. Distribution of Tourists who Visited Gili Matra TWP in 2014.

\begin{tabular}{|c|c|c|c|c|c|c|c|c|}
\hline \multirow[b]{2}{*}{ No } & \multirow{2}{*}{$\begin{array}{l}\text { Bulan/ } \\
\text { Month }\end{array}$} & \multicolumn{2}{|c|}{ Gili Trawangan } & \multicolumn{2}{|c|}{ Gili Meno } & \multicolumn{2}{|c|}{ Gili Air } & \multirow{2}{*}{$\begin{array}{c}\text { Jumlah/ } \\
\text { Total }\end{array}$} \\
\hline & & $\begin{array}{l}\text { Nusantaral } \\
\text { Domestic }\end{array}$ & $\begin{array}{c}\text { Asing/ } \\
\text { Foreign }\end{array}$ & $\begin{array}{c}\text { Nusantaral } \\
\text { Domestic }\end{array}$ & $\begin{array}{c}\text { Asing/ } \\
\text { Foreign }\end{array}$ & $\begin{array}{l}\text { Nusantarl } \\
\text { Domestic }\end{array}$ & $\begin{array}{c}\text { Asing/ } \\
\text { Foreign }\end{array}$ & \\
\hline 1 & Januari/January & 2.059 & 18.093 & 60 & 2.109 & 275 & 5.022 & 27.618 \\
\hline 2 & Pebruari/February & 3.399 & 16.545 & 94 & 2.179 & 287 & 4.503 & 27.007 \\
\hline 3 & Maret/March & 3.788 & 18.439 & 61 & 1.948 & 237 & 5.096 & 29.569 \\
\hline 4 & April/April & 3.953 & 22.823 & 107 & 2.317 & 313 & 5.623 & 35.136 \\
\hline 5 & Mei/May & 4.771 & 23.496 & 127 & 3.372 & 352 & 6.281 & 38.399 \\
\hline 6 & Juni/June & 4.713 & 25.671 & 136 & 3.109 & 147 & 7.011 & 40.787 \\
\hline 7 & Juli/July & 3.667 & 31.053 & 124 & 3.192 & 156 & 8.883 & 47.075 \\
\hline 8 & Agustus/August & 4.807 & 40.517 & 122 & 3.515 & 208 & 12.261 & 61.430 \\
\hline 9 & September/September & 3.008 & 26.778 & 102 & 2.470 & 196 & 7.942 & 40.496 \\
\hline 10 & Oktober/October & 3.097 & 19.518 & 76 & 2.643 & 225 & 7.183 & 32.742 \\
\hline 11 & Nopember/November & 2.869 & 14.698 & 68 & 2.695 & 25 & 6.489 & 26.844 \\
\hline 12 & Desember/December & 3.652 & 14.545 & 92 & 2.241 & 16 & 6.425 & 26.971 \\
\hline \multicolumn{2}{|c|}{ Jumlah/Total } & 43.783 & 272.176 & 1.169 & 31.790 & 2.437 & 82.719 & 434.074 \\
\hline \multicolumn{2}{|c|}{ Persentase/Percentage } & 14 & 86 & 4 & 96 & 3 & 97 & 868.148 \\
\hline \multicolumn{2}{|c|}{ Jumlah/Total } & & 315.959 & & 32.959 & & 85.156 & \\
\hline
\end{tabular}

Sumber: Dinas Pariwisata KLU, 2015 (diolah)/Source: KLU Tourism Office, 2015 (processed) 
menjamin terwujudnya kegiatan memproduksi barang atau jasa yang tinggi (optimal) efisiensinya.

Dari data pada Tabel 1 menunjukkan bahwa sebagian besar pengunjung berasal dari wisatawan asing yang berasal Amerika, Eropa, dan Asia. Sebesar 84\% wisatawan yang datang ke TWP Gili Matra merupakan wisatawan asing, dan sisanya $16 \%$ merupakan wisatawan domestik. Hal ini menunjukkan bahwa kawasan TWP Gili Matra merupakan kawasan yang paling digemari oleh wisatawan asing. Aktivitas wisata yang dominan dilakukan tidak hanya menyelam, tetapi aktivitas lain seperti wisata mancing, wisata snorkeling, wisata pantai, maupun wisata lainnya. Sedangkan wisatawan domestik yang berkunjung, lebih banyak menikmati wisata pantai atau wisata snorkling di pinggir pantai karena jenis wisata ini lebih tidak membutuhkan keterampilan khusus. Sedangkan syarat utama untuk menikmati wisata selam ini adalah harus punya sertifikat bisa menyelam yang dikeluarkan oleh lembaga PADI atau SSI. Kedua lembaga selam ini memberikan kursus mulai dari tingkat dasar hingga tingkat instruktur, sedangkan untuk mendapatkan serfitikat selam, harus mengeluarkan biaya sebesar 4,5 juta rupiah. Calon wisatawan selam ini akan dilatih cara dan teknik menyelam yang akan oleh instruktur yang bersertifikat.

Sebagian besar pengunjung mengunjungi Gili Trawangan sebagai tujuan berwisata. Baik wisatawan asing maupun wisatawan domestik. Kemudian Gili Meno, kemudian Gili Air. Tingginya tingkat kunjungan wisatawan ke Gili Trawangan karena fasilitas dan sarana prasarana seperti penginapan, restoran di pulau ini lebih lengkap dibanding dua pulau lainnya. Termasuk operator wisata selam, sebagian besar berlokasi di Gili Trawangan.

Dalam kegiatan usaha jasa wisata perairan di TWP Gili Matra, para penyedia jasa telah melakukan kesepatan tak tertulis untuk melakukan kartel. Kartel yang dimaksud adalah sebuah kesepakatan yang dibuat oleh para operator wisata selam yang ada di seluruh kawasan wisata TWP Gili Matra dan bekerja sama untuk menaikkan keuntungan masing-masing tanpa melalui persaingan usaha dengan pelaku usaha lainnya.

Kegiatan kartel ini dibawah naungan GIDA (Gili Islands Diving Assosiation). Mereka yang tergabung dalam asosiasi ini bersepakat untuk menentukan harga jual terendah kepada setiap pengguna jasa wisata selam. Selain harga jual, mereka juga sepakat untuk menentukan upah para guide, tenaga administrasi, dan instruktur selam. Implikasinya bagi konsumen adalah mereka tidak lagi punya peluang untuk mendapatkan harga yang lebih murah. Begitu juga dengan calon tenaga kerja, gaji tidak lagi kompetitif, padahal keahlian masing-masing tenaga kerja sangat bervariasi.

\section{Nilai Potensi Kerusakan Terumbu Karang}

Dari setiap aktivitas wisatawan di TWP Gili Indah sudah pasti berdampak terhadap kerusakan lingkungan, termasuk kerusakan lingkungan didalam perairan akibat kegiatan wisata selam. Kerusakan lingkungan inilah yang disebut dengan eksternalitas negatif terhadap lingkungan. Secara umum eksternalitas adalah suatu efek samping dari suatu tindakan pihak tertentu terhadap pihak lain, baik dampak yang menguntungkan, maupun yang merugikan. (Joseph E. Stiglitz, 1989, dalam Hukum Lingkungan Teori Legislasi dan Studi Kasus, HIm 159). Ada juga yang mendefinisikan eksternalitas sebagai aktivitas dari seserorang yang dapat mengganggu kenyamanan, kepuasan orang lain disekitarnya akibat perbuatan pihak pertama.

Dalam aktivitas wisata menyelam yang tidak bisa dikendalikan dan mengakibatkan menurunnya kualitas sumberdaya dan fungsi lingkungan disekitarnya, sehingga menimbulkan ketidakadilan bagi masyarakat, yang juga bergantung terhadap kualitas SDA atau lingkungan sekitarnya. Hasil pengamatan (Muhidin, 2017) mengklasifikasikan prilaku destruktif dari wisatawan selam menjadi dua, yaitu wisatawan non-sertifikat dan wisatawan bersertifikat. Kedua kelompok wisatawan memberikan peluang terjadinya kerusakan yang berbeda berdasarkan pengalaman mereka menyelam. Penyelam yang belum bersertifikat memiliki peluang melakukan kerusakan di dalam kawasan perairan lebih besar dibanding dengan wisatawan yang memiliki sertifikat. Selain itu, (Muhidin, 2017) menggolongkan perilaku destruktif wisatawan menjadi empak kegiatan yaitu menginjak terumbu karang, mengambil terumbu karang, menendang terumbu karang, dan memegang terumbu karang.

Dalam laporan (Kementerian Kelautan dan Kelautan, 2015) melaporakan bahwa terdapat 12,5 ha terumbu karang di TWP Gili Indah dalam kondisi baik, kemudian 106,24 ha dalam kondisi sedang, dan 112,63 ha atau $1.126 .300 \mathrm{~m}^{2}$ dalam kondisi buruk. Kerusakan tersebut ada yang 
disebabkan karena aktivitas manusia dan ada juga yang disebabkan karena cuaca. Namun belum ada data yang valid yang menjelaskan persentase kerusakan yang disebabkan oleh manusia atau oleh alam.

Peluang kerusakan akibat prilaku destruktif wisatawan tersebut setelah dikonversi menjadi luasan kawasan maka diketahui total luasan kawasan yang berpotensi rusak akibat prilaku destruktif wisatawan tersebut. Dengan frekuensi penyelaman sebesar 35.717 orang per tahun, maka diketahui prilaku menginjak karang dengan peluang 0,0037 per orang per penyelaman dapat menimbulkan kerusakan kawasan terumbu karang seluas 132.153 meter per tahun, selengkapnya dapat dilihat pada tabel 2 diatas. Luasan tersebut diperoleh dengan asumsi setiap penyelam memiliki daya dukung seluas 2 ribu meter persegi, dan wisatawan yang melakukan perilaku destruktif adalah separuh atau $50 \%$ dari wisatawan yang menyelam adalah wisatawan amatiran dan 50\% adalah wisatawan profesional yang diyakini tidak melakukan pengerusakan.

Dengan demikian, setelah dilakukan valuasi dengan menggunakan replacement cost atau biaya pengganti apabila kerusakan tersebut akan dikembalikan menjadi kondisi awal, maka dibutuhkan waktu dan biaya yang setara dengan nilai terumbu karang yang rusak tersebut. Eksternalitas negatif ini yang harus diinternalisasi oleh operator wisata sehingga menjadi bagian dari biaya produksi operator wisata. Hasil perhitungan valuasi diketahui bahwa nilai kerusakan sumberdaya akibat aktivitas wisata selam di Kawasan Wisata Perairan Gili Indah sebesar 129,8 miliyar rupiah dari kerusakan kawasan seluas $503.610 \mathrm{~m}^{2}$.

\section{Hubungan PES dengan Ekosistem Terumbu Karang}

PES merupakan salah satu instrument ekonomi yang digunakan untuk menjaga agar sumberdaya alam dapat dimanfaatkan secara berkelanjutan, baik sumberdaya di daratan maupun di perairan. Sumberdaya perairan yang banyak dimanfaatkan untuk kegiatan wisataadalah kawasan ekosistem terumbu karang yang dimanfaatkan untuk lokasi wisata selam. Namun dibeberapa lokasi saat ini, kawasan ekosistem terumbu karang yang dimanfaatkan sebagai kawasan wisata selam banyak yang tidak memperhatikan aspek keberlanjutan. Jumlah pengunjung tidak dibatasi dengan hanya untuk kepentingan ekonomi sesaat.
Menurut (Yulianda, Johan, Siregar, \& Karlina, 2007) pengembangan pariwisata berkelanjutan harus didasari pada prinsip dasar ekoswisata, yang meliputi:

- Mencegah dan menanggulangi dampak aktivitas wisata terhadap alam dan budaya dengan cara yang sesuai dengan karakter sosial budaya setempat.

- Memberikan pendidikan konservasilingkungan pada pelaku wisata dan masyarakat.

- Alokasi retribusi dan pajak untuk pengelolaan kawasan konservasi.

- Memotivasi dan meningkatkan peran masyarakat dalam proses pengelolaan kawasan.

- Masyarakat mendapat nilai ekonomi dari kegiatan wisata sehingga masyarakat termotivasi untuk menjaga kawasan.

- Pembangunan fasilitas wisata tetap menjaga keharmonisan dan keaslian alam.

- Daya dukung sebagai pembatas pembanguan fasilitas dan jumalah wisatawan.

- Kegiatan wisata harus memberikan kontribusi terhadap pendapatan pemerintah.

Kebijakan yang banyak dilakukan untuk mencegah kerusakan lingkungan adalah melalui mekanisme Payment for Environment (PES). Meskipun jasa lingkungan yang diperdagangkan dalam skema PES selama ini lebih banyak dilakukan pada jasa lingkungan yang ada di daratan seperti proteksi dan rehabilitasi Daerah Aliran Sungai (DAS), konservasi biodiversitas (biodiversity conservation), restorasi lanskap (landscape restoration), penyerapan karbon (carbon sequestration) dan stok karbon eksisting, serta keindahan alam (scenic beauty), namun PES juga sudah mulai diimplementasikan pada jasa lingkungan di perairan. PES untuk kawasan konservasi dan rehabilitasi juga sudah mulai dilakukan di kawasan ekosistem terumbu karang Taman Wisata Perairan Raja Ampat, dimana setiap wisatawan yang datang berkunjung dikenakan biaya tambahan yang dikumpulkan melalui operator wisata. Selanjutnya operator wisata akan menyetorkan kepada pemerintah daerah setempat secara berkala secuai dengan jumlah pengunjung yang datang.

Setiap orang yang melakukan kegiatan yang dapat merugikan orang lain maka orang tersebut 
harus memberikan kompensasi kepada setiap orang yang menderita akibat kegitan tersebut. Dalam prinsip ekonomi sumber daya alam, hal ini dikenal dengan istilah polluters pays principle $(P P P)$, artinya siapa yang membuat kerusakan maka dia harus membayar sejumlah nilai kerusakan itu. Ini adalah prinsip mendasar dalam hukum lingkungan AS. Prinsip Polluter-Pays berarti pencemar harus menanggung biaya tindakan pencegahan dan pengendalian pencemaran. Menurut Jephcote, Chenb \& Ropkins, (2016) pada dasarnya PPP bukanlah konsep keadilan, melainkan sebuah ukuran untuk memastikan efisiensi ekonomi dan meminimalkan distorsi dalam perdagangan internasional. Dengan memasukkan biaya lingkungan dalam proses pengambilan keputusan berarti pihak pengelola sumber daya harus mampu mengoptimalkan penggunaan sumber daya alam dengan meminimalkan pencemaran (Vicha, 2011).

Selama ini, besaran pungutan PES yang dikenakan kepada penerima manfaat adalah melalui hasil analisis Willingness to Pay (WTP) atau besaran keinginan membayar dari penerima manfaat. Dalam memperoleh nilai ini dilakukan melalui survei kepada beberapa masyarakat yang dijadikan sampel dari seluruh populasi penerima manfaat. Hasil dari survei tersebut kemudian di justifikasi sebagai WTP seluruh masyarakat yang menerima manfaat, tentunya dengan mempertimbangkan kapasitas produksi dari jasa lingkungan tersebut.

Namun dalam kajian ini, menawarkan pendekatan lain dalam menentukan besaran iuran PES yang dikenakan kepada wisatawan yang menerima manfaat atas keberadaan ekosistem terumbu karang. Dasar pemikiran pengenaan iuran PES terhadap wisatawan yang melakukan wisata selam di TWP Glli Matra ini adalah karena terumbu karang memberikan nilai estetika yang menjadi daya tarik bagi wisatawan. Jika keindahannya hilang maka hilang pula daya tarik terumbu karang bagi wisatawan. Jika daya tarik wisatawan hilang maka hilang pula nilai ekonomi dari terumbu karang untuk wisata selam. Agar keindahan dari ekosistem terumbu karang tersebut tidak hilang, maka BKKPN sebagai pengganti BSDA selaku pengelola kawasan harus tetap menjaga kelestarian ekosistem terumbu karang. Biaya pengelolaan selama ini masih mengandalkan anggaran dari negara (APBN) yang dianggarkan rutin setiap tahun. Namun dengan mekanisme PES ini, biaya tidak lagi mengandalkan dari APBN, tetapi cukup dari wisatawan yang datang menikmati keindahan sumber daya tersebut.

Tujuan utama wisatawan melakukan wisata selam adalah untuk menikmati keindahan alam bawah laut dan keanekaragaman hayati yang ada didalamnya. Apalagi di kawasan TWP Gili Matra dikenal dengan keberadaan Blue Coral (terumbu karang biru). Terumbu karang biru ini termasuk terumbu karang langka dan hanya terdapat di beberapa tempat saja di dunia, termasuk di TWP Gili Matra. Keunikan ini tersebar hingga ke seluruh dunia, dan dijadikan sebagai salah satu daerah tujuan wisata selam internasional, sehingga banyak operator wisata memperoleh manfaat ekonomi yang besar dengan menjual paketpaket wisata kepada calon wisatawan. Untuk menunjang kegiatan wisata di kawasan ini, pemerintah telah membangun infrastruktur seperti darmaga, penyediaan air bersih, listrik, perbankan, serta sarana publik lainnya, sedangkan pihak swasta menyediakan jasa akomodasi, konsumsi, transportasi, serta kebutuhan perlengkapan penunjang wisata selam.

Konsep pemanfaatan sumber daya yang selama ini terjadi di TWP Gili Matra adalah masih konsep ekonomi konvensional. Dimana penyedia jasa hanya menghitung biaya-biaya yang riel terjadi. Penyedia jasa tidak memperhitungkan biaya ekologi yang muncul dari setiap aktivitas wisatawan. Dalam konsep ekonomi sumber daya alam, setiap orang yang memperoleh manfaat dari keberadaan sumber daya alam, maka mereka harus membayar kompensasi kepada pemilik sumber daya. Dasar pemikiran untuk memungut biaya dari penerima manfaat adalah berdasarkan teori beneficiary pays atau penerima manfaat membayar (Pagiola, 2004). Dengan demikian, pengelola kawasan berhak memungut biaya dari wisatawan selaku penerima manfaat atas keberadaan terumbu karang di TWP Gili Matra.

Payment for Environmental Services (PES) atau kompensasi jasa ekosistem (PJL) merupakan pemberian imbal jasa berupa pembayaran finansial dan/atau non finansial kepada pengelola lahan atas jasa ekosistem yang dihasilkan. Kepuasan wisatawan dalam menikmati keindahan ekosistem terumbu karang yang berada di alam bawah laut, harus dibayar secara finansial kepada pengelola kawasan, baik secara langsung maupun melalui agen-agen wisata yang mereka gunakan. 


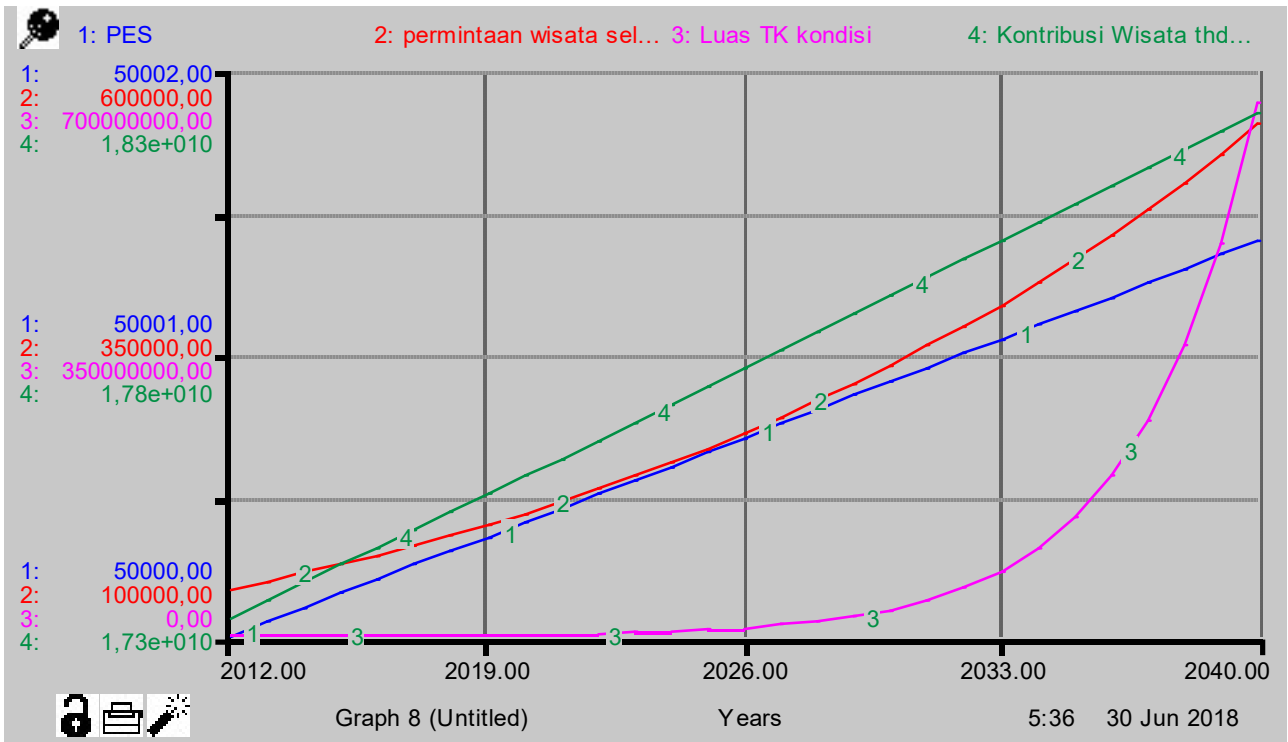

Gambar 1. Hubungan PES dengan Pertumbuhan Terumbu Karang. Figure 1. Relationship Between PES and Coral Reef Growth.

Gambar 1 di atas menunjukkan bahwa iuran PES terus mengalami peningkatan seiring dengan peningkatan jumlah kunjungan wisata. Dengan demikian, pertumbuhan kualitas terumbu karang juga akan mengalami peningkatan dengan asumsi bahwa semua dana iuran dari wisatawan dialokasikan untuk kegiatan konservasi dan jumlah pengunjung yang datang tidak melebihi batas DDK yang ditentukan. Gambar 1 menunjukkan besaran PES eksisting, dimana pengaruh PES dengan iuran sebesar 50 ribu rupiah per wisatawan, diikuti dengan pertumbuhan kualitas terumbu karang yang terus meningkat. Dengan demikian, semakin besar iuran PES maka pertumbuhan ekosistem terumbu karang akan semakin tinggi, dengan asumsi tingkat pertumbuhan lebih tinggi dibandingkan dengan tingkat kerusakan. Sehingga pada tahun 2039 diperkirakan terjadi pertumbuhan yang optimal, dimana terjadi pertemuan antara garis iuran PES dengan pertumbuhan ekosistem terumbu karang. Artinya tidak ada lagi pertumbuhan terumbu karang, dan iuran $P E S$ tidak lagi dipergunakan untuk program transpalantasi atau pembuatan biorock, tetapi iuran tersebut dapat dialihkan untuk program konservasi lainnya.

Pertumbuhan kualitas terumbu karang tidak linier karena ada faktor kerusakan alamiah dan kerusakan akibat aktivitas manusia. Namun persentase kerusakan masih lebih kecil dibandingkan dengan persentase pertumbuhan, baik pertumbuhan secara alami maupun pertumbuhan dari program konservasi. Pemulihan kondisi ekosistem terumbu karang turut dipengaruhi oleh banyaknya biorock (rumah terumbu karang) yang dibangun dan program transpalantasi terumbu karang yang dilakukan. Kedua program tersebut membutuhkan dana yang besar untuk mencapai target pemulihan yang diinginkan. Sedangkan sumber pendanaan kegiatan tersebut selama ini hanya mengandalkan dari APBN, sumbangan pihak swasta dan iuran dari wisatawan yang belum dikelola optimal.

\section{SKEMA PES EKSISTING}

Sebagian besar program PES di Indonesia dilaksanakan di kawasan hutan (Fauzi \& Anna, 2013). Pendekatan skema PES yang banyak diaplikasikan pada sumber daya yang ada di darat, khususnya sumber daya air (DAS). Namun dalam kerangka regulasi lokal, peluang untuk penerapan PES dalam pengelolaan sumberdaya pesisir dan laut di atur dalam Peraturan Desa (Perdes) Desa Gili Indah nomor 03 tahun 2014. Dalam Perdes ini memberikan peluan guntuk membentuk organisasi atau lembaga pengelola sumberdaya laut dan pesisir di kawasan Desa Gili Indah. Setiap peningkatan aktivitas dari wisatawan yang datang berwisata, akan memberikan peluang lebih besar terhadap kerusakan sumberdaya yang ada disekitarnya. Peningkatan kunjungan ini menurut (Kusumastanto, 1995) dapat menimbulkan risiko tinggi pencemaran lingkungan dan gangguan ekosistem. 
luran yang dipungut dari wisatawan yang mirip dengan iuran $P E S$ ini sudah mulai diterapkan di kawasan ini ketika penyedia jasa wisata selam mulai sadar setelah melihat kualitas ekosistem terumbu karang yang terus mengalami penurunan. Aktivitas wisatawan yang dapat merusak ekosistem terumbu karang antara lain dari kegiatan pengambilan terumbu karang, menginjak terumbu karang, dan menendang terumbu karang. Berdasarkan prinsip PES, dimana setiap orang yang mendapatkan kepuasan dari keberadaan sumber daya alam, maka orang tersebut harus memberikan konpensasi berupa sejumlah uang untuk menjaga kelestarian sumber daya tersebut.

Model skema pembayaran yang mirip dengan PES oleh wisatawan kepada pengelola lingkungan sudah mulai dilakukan sejak berdirinya Gili Indah Dive Association (GIDA). Dana PES selama ini dipungut oleh GIDA kepada setiap wisatawan selam. Setiap wisatawan hanya diwajibkan membayar iuran jasa lingkungan sebesar 50 ribu rupiah per orang, dan hanya dikenakan satu kali saja, untuk kunjungan berikutnya tidak akan dikenakan lagi. Dana ini kemudian disetorkan kepada Yayasan Eco Trust yang berlokasi di Gili Trawangan. Dana tersebut kemudian digunnakan untuk biaya operasional, biaya pengawasan dan biaya pembuatan terumbu karang buatan di tempat-tempat terumbu karang yang sudah rusak. Adapun skema pemungutan PJL/PES yang diterapkan hingga saat ini yang dilaksanakan oleh LSM dan GIDA.
Kelemahan dari skema ini adalah tidak adanya laporan pertanggungjawaban jumlah dana yang diterima dan laporan penggunaan dana kepada pemerintah maupun kepada masyarakat. Terjadi peluang penyalahgunaan uang pungutan oleh operator wisata juga sangat besar. Pihak GIDA juga tidak ada yang mengaudit jumlah pungutan yang dipungut operator wisata, dan pihak yayasan Eco Trust juga tidak bisa mengaudit pihak GIDA mengenai jumlah setoran yang diterima dari masing-masing operator wisata.

Begitu juga halnya dengan penggunaan dana yang tidak transparan oleh pihak GIDA, hal ini menyebabkan ketidakpercayaan antara GIDA selaku pemungut dana dari wisatawan dengan Yayasan Eco Trust selaku pelaksana konservasi terumbu karang. Begitu juga dengan proses pemungutan dana juga tidak disertai dengan tanda terima yang resmi dari GIDA. Walau demikian, para wisatawan tidak ada yang keberatan atas pungutan tersebut.

\section{SKEMA BARU PES}

Belajar dari kelemahan pada sistem pembayaran PES dari wisatawan kepada GIDA, kemudian GIDA ke Yayasan Eco Trust, maka harus dibuatkan skema baru yang lebih efektif dan efisien. Dasar hukum pungutan PES harus jelas dan dapat dipertanggungjawabkan kepada masyarakat. Skema PES selalu terkait dengan aspek kelembagaan baik yang menyangkut aspek legal maupun kebijakan yang ada di sekitar

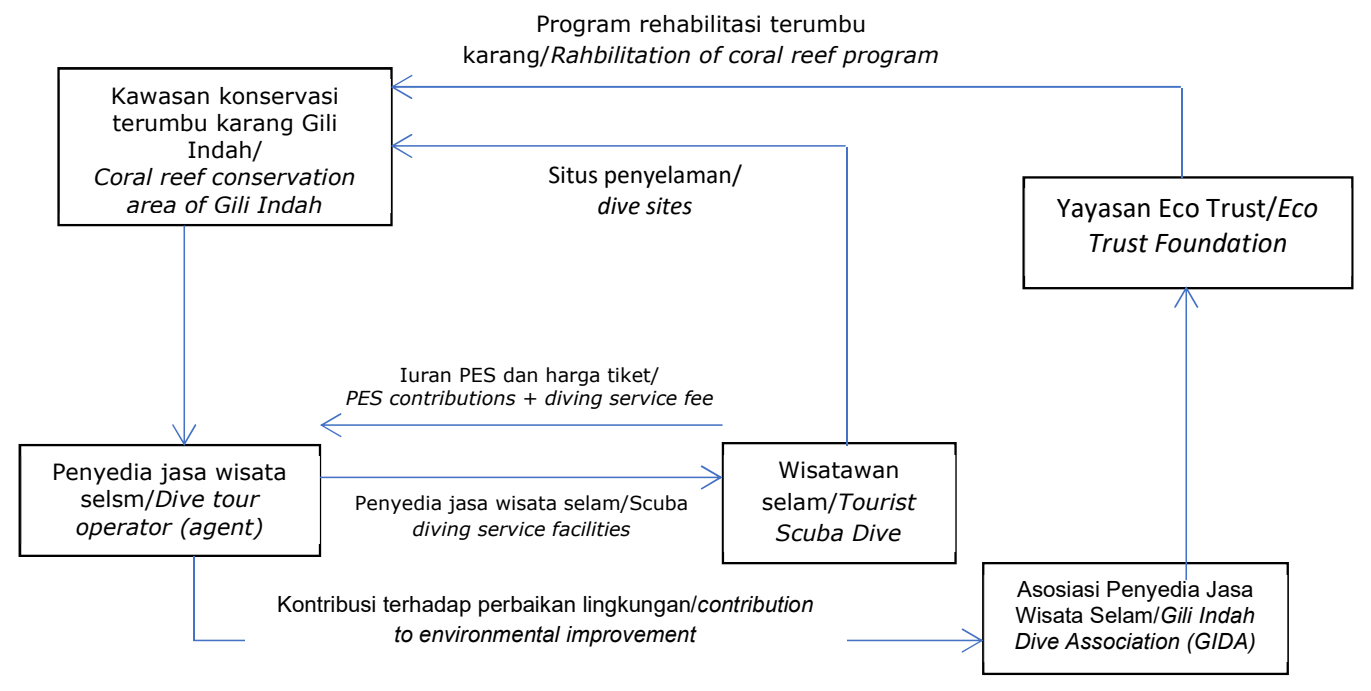

Gambar 2. Skema PES Saat Ini.

Figure 2. Existing PES Scheme. 
kawasan wisata selam. Aspek kelembagaan yang sejalan dengan aspek PES akan memudahkan pelaksanaan $P E S$, sehingga paling tidak konflik dan permasalahan akan dapat ditekan seminim mungkin. Hasil penelitian (Berkes, 2004) dalam (Batavia, Bruskotter, Jones, Vecetich, Gosnell \& Nelson, 2018) menjelaskan bahwa Inisiatif konservasi yang berhasil sering membutuhkan dukungan dari masyarakat lokal. Oleh karena itu, melibatkan masyarakat dalam pengelolaan dana iuran untuk perbaikan lingkungan sangat diperlukan.

Setidaknya ada tiga pihak yang terlibat dalam pelaksanaan skema PES di TWP Gili Matra, yaitu: wisatawan, operator wisata, dan BKKPN. Agar skema PES ini dapat diterima oleh masingmasing pihak, maka semua pihak harus diikat dalam satu kontrak perjanjian, baik dalam bentuk $\mathrm{MoU}$ maupun kontrak legal. Kontrak maupun MoU yang akan dibuat harus secara eksplisit menyebutkan jumlah nominal PES yang harus dibayarkan oleh wisatawan selaku penerima manfaat kepada BKKPN selaku pengelola kawasan, serta sebagai pelaku utama menjaga kelestarian ekosistem terumbu karang, sedangkan operator wisata selalu penyedia fasiltitas untuk melakukan wisata bertugas memungut $P E S$ dari wisatawan dan menyetorkan secara berkala kepada BKKPN sesuai dengan jumlah yang telah disepakati. Dalam hal ini mekanisme pengelolaan dana PES yang diusulkan adalah mekanisme kolaboratif, dimana dana yang diterima BKKPN kemudian disetorkan kepada kas negara melalui mekanisme Penerimaan Negara Bukan Pajak (PNBP). BKKPN kemudian mengajukan kebutuhan anggaran yang dibutuhkan untuk biaya konservasi kawasan, seperti terlihat pada Gambar 3.

Mekanisme jenis PES ini paling banyak digunakan di negara-negara berkembang (Danida, 2011), tak terkecuali di Indonesia. BKKPN selaku pengelola kawasan tidak bisa melakukan pungutan langsung kepada setiap wisatawan. Hal ini disebabkan karena keterbatasan SDM yang ada dan faktor efisiensi pemungutan. Jika pungutan dilakukan oleh operator wisata, maka pungutan tersebut bisa include menjadi satu ke dalam harga paket wisata. Operator wisata tinggal menyisihkan pungutan untuk $P E S$ yang dibayarkan oleh wisatawan, kemudian disetorkan kepada kas negara untuk biaya operasional BKKPN.

Dalam kontrak perjanjian antara penyedia jasa dengan pengelola kawasan harus ditetapkan bahwa setiap wisatawan. Pembayaran iuran PES dikenakan kepada setiap wisatawan dikalikan prekuensi penyelaman. Jika penyelaman hanya dilakukan sekali dalam sehari, maka pungutan dilakukan satu kali saja. Namun jika penyelaman dilakukan dua kali dalam sehari, meskipun lokasi penyelaman dilakukan ditempat yang sama, maka

Program Konservasi Terumbu

Karang/Rahbilitation of coral reef program

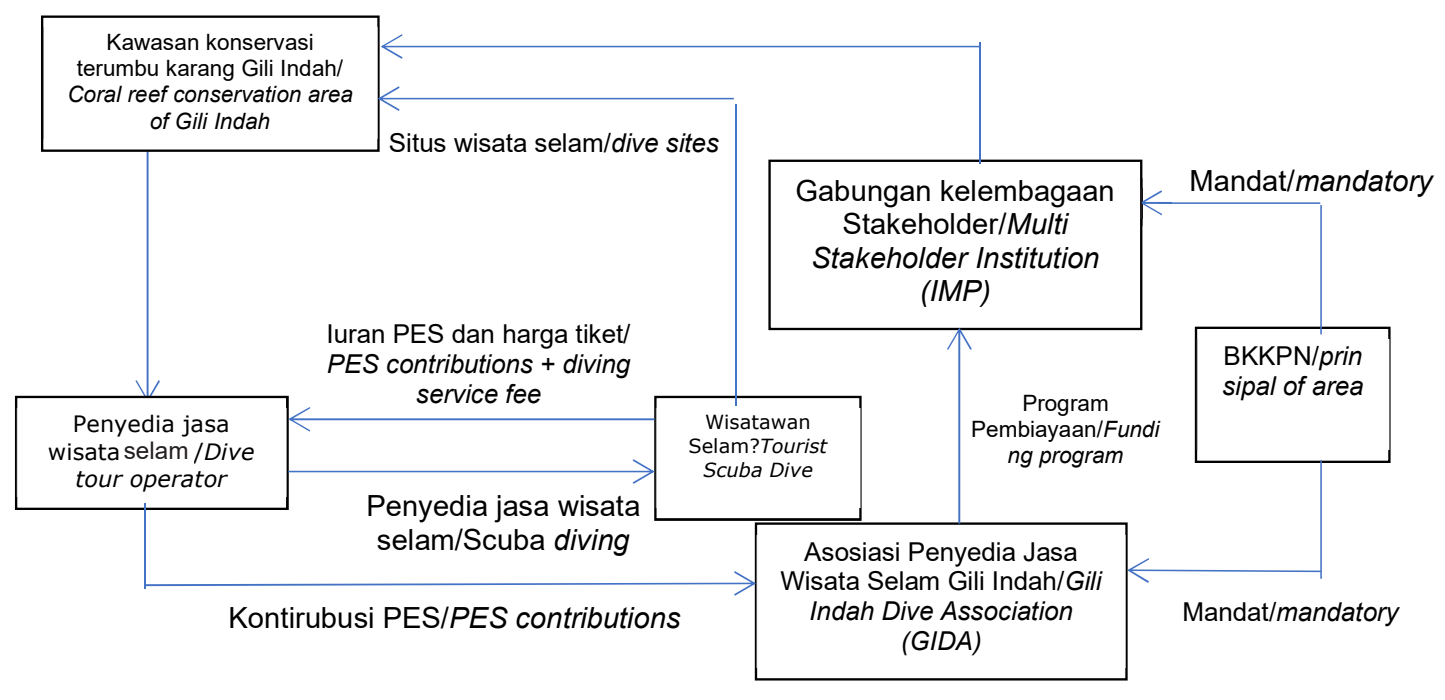

Gambar 3. Skema PES Sebagai PNBP.

Figure 3. PES Schemes As Non-Tax Revenue. 
pungutan dilakukan dua kali juga. Tipe pungutan ini diberlakukan sama dengan tipe penjualan jasa yang dilakukan oleh setiap operator wisata. Selama ini, wisatawan yang datang sebagian besar melakukan penyelaman lebih dari satu kali dalam sehari. Sebagian besar penyedia jasa wisata menjual paket wisata selam selama empat kali dalam sehari yaitu dari jam 09-10, 11-13, 14-16, dan jam 19-21. Tidak semua operator wisata menjual jasa wisata selam night dive karena terkendala tenaga pemandu wisata (guide) yang ahli menyelam pada malam hari yang terbatas, meskipun permintaan terhadap jenis wisata malam ini cukup banyak.

\section{PENUTUP}

PES memberikan kontribusi yang signifikan terhadap pertumbuhan kualitas terumbu karang di TWP Gili Matra. Mekanisme pengelolaan yang baik dan benar akan memberikan dampak yang optimal terhadap program konservasi. Pemerintah saja tidak cukup untuk menjaga kelestarian sumberdaya yang ada di dalam kawasan konservasi, maka perlu melibatkan seluruh stakeholder yang terkait untuk bersinergi menjadi satu kekuatan yang memberikan kontribusi yang optimal.

Munculnya eksternalitas negatif disebabkan karena tidakadanya aturan yang jelas yang membatasi aktivitas wisatawan. Eksternalitas negatif yang dihasilkan dari aktivitas wisatawan yang melakukan kegiatan selam menunjukkan tren yang terus meningkat. Untuk mengembalikan kondisi sumber daya terumbu karang kepada kondisi yang ideal, diperlukan anggaran yang besar dan waktu yang tidak singkat. Anggaran pemerintah untuk melakukan konservasi tidak mencukupi untuk membiayai program konservasi. Sedangkan iuran wisatawan untuk berpartisipasi dalam melestarikan sumber daya tidak efisien karena tidak ada kelembagaan pengelolaan yang baik. Oleh karena itu, manajemen pengelolaan iuran wisatawan untuk perbaikan sumber daya perlu dibenahi dengan melibatkan BKKPN dalam pengelolaan. Prinsip iuran PES sangat tepat untuk diterapkan agar iuran tersebut dapat dikelola dengan baik. Selain itu, terjadi ketidak adilan dalam pemanfaatan sumber daya terumbu karang, dimana BKKPN selaku pengelola kawasan tidak memperoleh kompensasi dari wisatawan yang memperoleh manfaat dari keberadaan terumbu karang. Sedangkan biaya pengelolaan untuk melindungi ekosistem terumbu karang masih dibebankan kepada BKKPN.
Berdasarakan uraian kesimpulan di atas maka dapat disarankan kepada pemerintah agar melakukan komunikasi dengan seluruh stakeholders yang terkait dengan aktivitas wisata di kawasan TWP Gili Matra. BKKPN selaku pengelola kawasan diharapkan mulai menginisiasi secara legal formal memiliki kewenangan yang besar untuk mengatur seluruh stakeholders yang ada. Dalam rangka mencegah eksploitasi sumber daya kelautan yang berlebihan, maka para pelaku usaha harus diatur dan ditata penempatannya. BKKN sebagai prinsipal harus mampu memerankan fungsinya dengan baik dan para agen harus mentaati kewajibannya sebagai agen. Jika aktivitas masyarakat tidak dibatasi dengan aturan yang jelas penegakan hukum yang tegas, maka sumber daya alam akan cepat punah.

\section{UCAPAN TERIMA KASIH}

Penulis mengucapkan terima kasih kepada Prof. Dr. Ir. Tridoyo Kusumastanto selaku ketua komisi pembimbing, Prof. Dr. Ir. Akhmad Fauzi, M.Sc dan Dr. Ir. Fredinan Yulianda, M.Sc selaku anggota komisi pembimbing, serta LPDP (Lembaga Pengelola Dana Pendidikan) Kementerian Keuangan Republik Indonesia atas bantuan dana beasiswa penelitian disertasi tahun 2015-2016 ini.

\section{DAFTAR PUSTAKA}

Bachmann, T. \& J.V. Kamp. (2017). Expressing air pollution-induced health-related externalities in physical terms with the help of DALYs. Environment International, 39-50.

Batavia, C. J.T. Bruskotter, J.A. Jones, J.A. Vecetich, H. Gosnell \& M.P. Nelson. (2018). Nature for whom? How type of beneficiary influences the effectiveness of conservation outreach messages. Biolocigal Conservation 228, 158-166

Danida. (2011). Protokol Pembayaran Jasa Lingkungan (PJL) (Protocol of Payment For Environmental Services). Bogor: LPM EQUATOR.

Departemen Kelautan dan Perikanan. (2003). Valuasi Ekonomi Kawasan Konservasi Laut. Jakarta: Direktorat Jenderal PESisir dan Pulau-Pulau Kecil, Direktorat Konservasi dan Taman Nasional Laut.

Dinas Pariwisata Kabupaten Lombok Utara. (2014). Data Perkembangan Kunjungan Wisatawan Tahun 2015.

Dispenda. (2015). Realisasi Pendapatan Asli Daerah Kabupaten Lombok Utara. Tanjung: Dinas Pendapatan Daerah Kabupaten Lombok Utara. 
Fauzi, A. \& Z. Anna. (2013). The Complexity of the institution of payment for environmental services: A case study of two Indonesian PES Schemes. Scinece Direct, 65.

Jephcote, C., H. Chenb \& K. Ropkins. (2016). Implementation of the Polluter-Pays Principle (PPP) in local transport policy. Journal of Transport Geography, 55 (2016) 58-71, 58-71.

Kementerian Kelautan dan Kelautan, R. (2015). Rencana Pengelolaan dan Zonasi Taman Wisata Perairan Pulau Glli Ayer, Gili Meno dan Gili Trawangan di Provinsi Nusa Tenggara Barat tahun 2014-2034. Jakarta: Direktorat Konservasi dan Keanekaragaman Hayati Laut.

Kementerian Kelautan dan Perikanan. (2013). Informasi Kawasan Konservasi Perairan Indonesia. Jakarta: Direktorat Konservasi Kawasan dan Jenis Ikan Direktoran Jenderal Kelautan, Pesisir, dan Pulau-pulau Kecil Kementerian Kelautan dan Perikanan.

Keputusan Menteri Nomor 67/MEN/2009 tentang Penetapan Kawasan Konservasi Perairan Nasional Pulau Gili Ayer, Gili Meno, dan Gili Trawangan di Provinsi Nusa Tenggara Barat

Kusumastanto, T. (1995). Investasi, Pertumbuhan Ekonomi dan Pembangunan Berkelanjutan. Jakarta: Kompas.

Muhidin. (2017). Kajian Daya Dukung Ekosistem Terumbu Karang Berdasarkan Potensi Dampak Wisata Bahari di Kelurahan Pulau Panggang Kepulaun Seribu. Bogor: Institut Pertanian Bogor.

Pagiola, S. (2004). Environmental Services Payments in Central America: Putting Theory into Practice. Presented at the-Environmental Economics for Development Policyll Training Course. World Bank Institute.

Peraturan Pemerintah Republik Indonesia Nomor 46 Tahun 2017 Tentang Instrumen Ekonomi Lingkungan Hidup.

Perdes Gili Indah. (2010). Rencana Pembangunan Jangka Menengah Desa Gili Indah Tahun 2010 - 2014. Pemenang: Pemerintah Desa Gili Indah.

Solihin, L. (2008). Analisa Biaya-Manfaat Program Konservasi Terumbu Karang di Desa Gili Indah, Kabupaten Lombok Barat, Provinsi Nusa Tenggara Barat. Bogor: Institut Pertanian Bogor.

Surat Keputusan Menteri Kehutanan Nomor: 99/ Kpts-II/2001.

Vicha, O. (2011). The Polluter-Pays Principle in OECD recommendations and its application in international and EC/EU law. Czech Yearb. Public Priv. Int. Law, 56-57.
Yulianda, F., Johan, Y., Siregar, V. P., \& Karlina, I. (2007). Ekowisata Bahari Sebagai Alternatif Pemanfaatan Sumberdaya. Seminar Sains Departemen Manajemen Sumberdaya Perairan, Fakultas Perikanan dan IImu Kelautan, Institut Pertanian Bogor (p. 129). Bogor: Institut Pertanian Bogor.

Zhu, L. \& Y.C. Zhao. (2015). A feasibility assessment of the application of the Polluter-Pays Principle toship-source pollution in HongKong. Marine Policy, 57, 36-44. 